\title{
Multi-factor impact analysis of agricultural production in Bangladesh with climate change
}

\author{
Alex C. Ruane ${ }^{\mathrm{a}, *}$, David C. Major ${ }^{\mathrm{b}}$, Winston H. Yu ${ }^{\mathrm{c}}$, Mozaharul Alam ${ }^{\mathrm{d}, \mathrm{h}}$, Sk. Ghulam Hussain ${ }^{\mathrm{e}, \mathrm{g}}$, \\ Abu Saleh Khan ${ }^{\mathrm{f}}$, Ahmadul Hassan ${ }^{\mathrm{g}}$, Bhuiya Md. Tamim Al Hossain ${ }^{\mathrm{g}}$, Richard Goldberg ${ }^{\mathrm{b}}$, \\ Radley M. Horton ${ }^{\mathrm{b}}$, Cynthia Rosenzweig ${ }^{\mathrm{a}}$ \\ ${ }^{\text {a }}$ NASA Goddard Institute for Space Studies, New York, NY, United States \\ ${ }^{\mathrm{b}}$ Columbia University Earth Institute Center for Climate Systems Research, New York, NY, United States \\ ${ }^{c}$ The World Bank, Washington, DC, United States \\ d Bangladesh Centre for Advanced Studies (BCAS), Dhaka, Bangladesh \\ ${ }^{\text {e }}$ Bangladesh Agricultural Research Council (BARC), Dhaka, Bangladesh \\ ${ }^{\mathrm{f}}$ Institute of Water Modelling (IWM), Dhaka, Bangladesh \\ ${ }^{\mathrm{g}}$ Center for Environmental and Geographic Information Services (CEGIS), Dhaka, Bangladesh \\ ${ }^{\mathrm{h}}$ United Nations Environment Programme Regional Office for Asia and the Pacific, Bangkok, Thailand
}

\section{A R T I C L E I N F O}

\section{Article history:}

Received 6 April 2011

Received in revised form 10 May 2012

Accepted 26 September 2012

Available online 10 November 2012

\section{Keywords:}

Climate change

Climate impacts

Agriculture

Bangladesh

Rice

Wheat

Crop modeling

DSSAT

Floods

Sea level rise

Adaptation

\begin{abstract}
A B S T R A C T
Diverse vulnerabilities of Bangladesh's agricultural sector in 16 sub-regions are assessed using experiments designed to investigate climate impact factors in isolation and in combination. Climate information from a suite of global climate models (GCMs) is used to drive models assessing the agricultural impact of changes in temperature, precipitation, carbon dioxide concentrations, river floods, and sea level rise for the 2040-2069 period in comparison to a historical baseline. Using the multi-factor impacts analysis framework developed in $\mathrm{Yu}$ et al. (2010), this study provides new sub-regional vulnerability analyses and quantifies key uncertainties in climate and production. Rice (aman, boro, and aus seasons) and wheat production are simulated in each sub-region using the biophysical Crop Environment REsource Synthesis (CERES) models. These simulations are then combined with the MIKE BASIN hydrologic model for river floods in the Ganges-Brahmaputra-Meghna (GBM) Basins, and the MIKE21 Two-Dimensional Estuary Model to determine coastal inundation under conditions of higher mean sea level. The impacts of each factor depend on GCM configurations, emissions pathways, sub-regions, and particular seasons and crops. Temperature increases generally reduce production across all scenarios. Precipitation changes can have either a positive or a negative impact, with a high degree of uncertainty across GCMs. Carbon dioxide impacts on crop production are positive and depend on the emissions pathway. Increasing river flood areas reduce production in affected sub-regions. Precipitation uncertainties from different GCMs and emissions scenarios are reduced when integrated across the large GBM Basins' hydrology. Agriculture in Southern Bangladesh is severely affected by sea level rise even when cyclonic surges are not fully considered, with impacts increasing under the higher emissions scenario.
\end{abstract}

Published by Elsevier Ltd.

\section{Introduction}

Bangladesh (Fig. 1) lies on mostly flat, alluvial land at the mouth of the Ganges-Brahmaputra-Meghna (GBM) Basins that drain monsoon runoff from a large portion of South Asia, and is widely recognized as a country with high sensitivity to climate variability and change. Bangladesh uses more than $70 \%$ of its land for

\footnotetext{
* Corresponding author at: NASA Goddard Institute for Space Studies, 2880 Broadway, New York, NY 10025, United States.

E-mail address: alexander.c.ruane@nasa.gov (A.C. Ruane).
}

agricultural purposes (FAOSTAT, 2009), often with multiple cropping seasons, and nearly all of the remainder is covered by forests, settlements, roads and waterways (MPO, 1986). Bangladesh also has high population density, with a current population equivalent to half of the population of the United States living in an area the size of the state of Iowa. Long-term climate threats include a changing distribution of river floods, sea level rise in the Bay of Bengal, warming temperatures, and changing rainfall patterns, which can exacerbate current vulnerability to climate extremes and variations and pose a substantial challenge in producing enough food for a growing and developing population (Huq, 2001; Huq et al., 2003; Parry et al., 2004; Asada and 


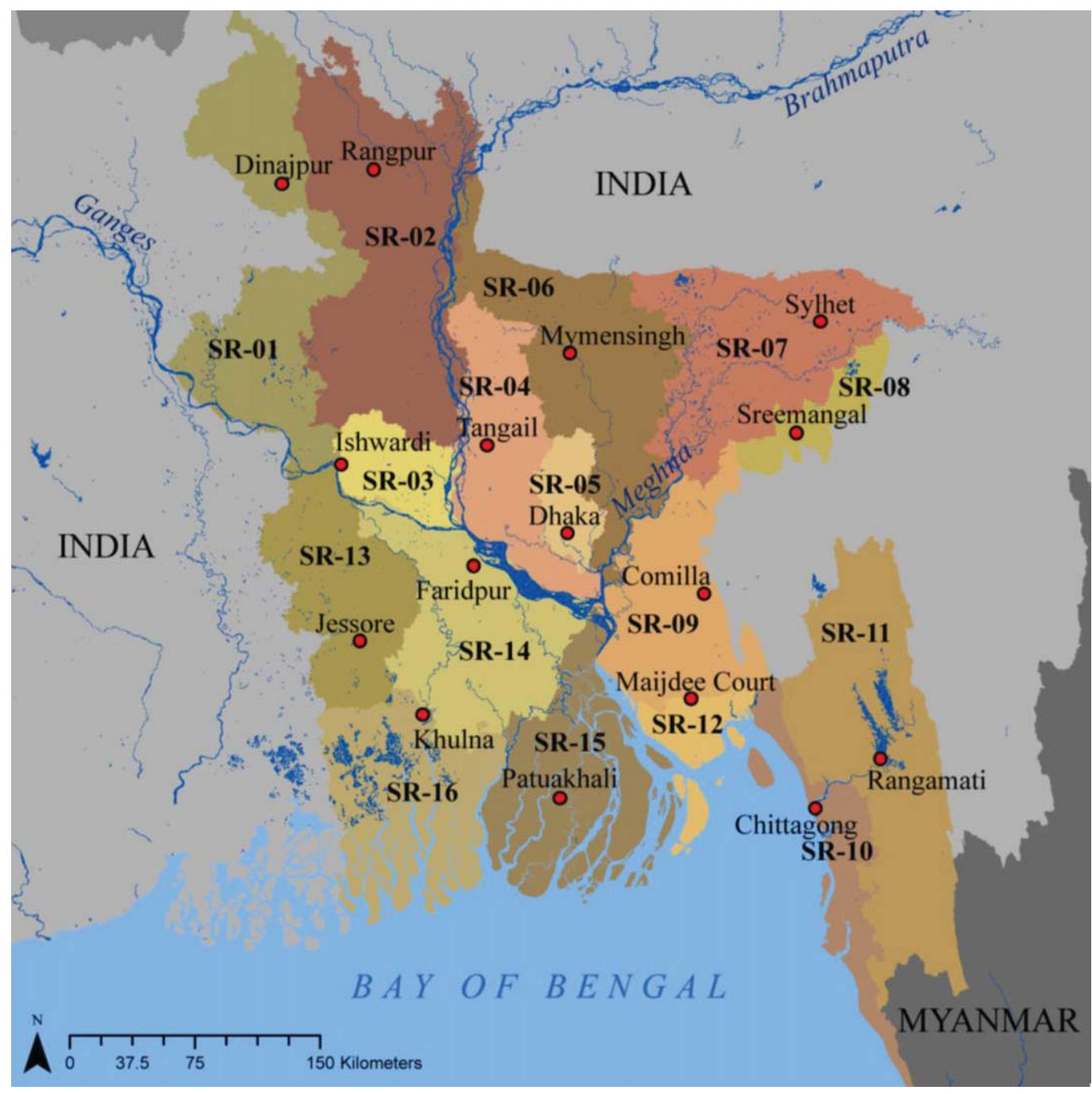

Fig. 1. Bangladesh sub-regions as defined for this study, with sentinel weather stations and major rivers.

Matsumoto, 2009). A beneficial climate impact comes from a key driver of global climate change, as elevated carbon dioxide $\left(\mathrm{CO}_{2}\right)$ concentrations enhance photosynthetic production and water efficiency in crops to a limited extent (Easterling et al., 2007; Fleischer et al., 2010; Kimball, 2010). These processes are among the complex challenges facing farmers in Bangladesh, and the experiments presented in this study elucidate the agricultural responses to projected climate conditions that are unprecedented in recent history.

Bangladesh's precarious position with respect to climate change has elevated awareness of national vulnerabilities both domestically and internationally. There have been numerous studies of climate change impacts in Bangladesh, but they have provided climate projections without quantifying agricultural impacts or tended to examine just a subset of the impact factors that are inter-compared and combined here. Rahman et al. (2009) conducted a comprehensive overview of climate change projections for temperature, rainfall, river floods, and sea level rise for various Bangladeshi sub-regions and identified adaptation strategies geared to particular impact factors and vulnerabilities from interviews and stakeholder workshops. Similar climate change impact reviews are provided by Agrawala et al. (2003), Ahmed (2006), and Tanner et al. (2007). Other studies of climate change impacts on Bangladeshi rice have focused primarily on coastal flooding impacts (Ali, 1999; Sarwar, 2005), temperature and carbon dioxide effects (Karim et al., 1994, 1998; Timsina et al.,
1997; Mahmood, 1997, 1998; Timsina and Humphreys, 2006; Basak et al., 2009), or river flood impacts (Hassan et al., 2008). Much work has also been done to identify and test adaptation strategies (Huq et al., 1999; Ministry of Environment and Forests, 2005; Adger et al., 2007; Thomalla et al., 2005; Ayers and Forsyth, 2009; Rahman et al., 2009), and in 2009 the Government of Bangladesh released its Climate Change Strategy and Adaptation Plan (Ministry of Environment and Forests, 2009).

Government programs (including the construction of embankments and coastal protection), private enterprise (including the expansion of electrified pump-irrigation systems), crop breeders (developing drought, flood, or salinity resistant seeds), small farmholders (changing planting dates and/or farm management practices) and international partners (e.g. the World Bank, The Global Environmental Facility) all have roles to play to build efficient climate resilience and adaptive capacity. For a list of past and present programs on adaptation in the agricultural sector, see Table 7.1 of Yu et al. (2010). Funds are limited, however, so major adaptation programs must be carefully prioritized to maximize utility.

This study aims to identify the critical climate factors and associated uncertainties in agricultural impacts for each of 16 subregions in Bangladesh in order to form a basis for prioritizing adaptation measures. The impacts of changes in temperature, precipitation, $\mathrm{CO}_{2}$ concentration, river flooding, and sea level rise on agricultural production are investigated through simulations 
where each climate factor is investigated independently. Then, an integrated multi-factor analysis allows for sub-regional scale examination of the impacts of all climate factors in combination to form a framework that may be used to identify and prioritize adaptation strategies. This work is an extension of the crop modeling portion of a World Bank report on climate change risks in the agricultural sector of Bangladesh (Yu et al., 2010), adding increased analysis of sub-regional vulnerability and adaptation priorities, distinguishing sub-regionally between temperature and rainfall impacts, as well as tracking and quantifying sources of uncertainty in each sub-region.

\section{Agriculture in Bangladesh}

Agriculture is a pillar of Bangladesh's economy, using more than $70 \%$ of land area (FAOSTAT, 2009) and accounting for nearly $20 \%$ of gross domestic product and 65\% of the labor force, employed primarily on small-holder farms (Yu et al., 2010). Rice production occurs on more than $80 \%$ of agricultural lands and is grown in three growing seasons that span the entire year and are synonymous with their rice crop: aman, boro, and aus (BBS, 2005, 2008). Aman grows during the monsoon season when rainfall is plentiful. Boro is grown during the dry season, after floods have receded, and is restricted to irrigated areas. Aus production takes advantage of rainfall during the spring transition toward the monsoon that enables a short growing season, although the sufficiency of rains varies from year to year. Rice cultivation makes up nearly 95\% of cereal production in Bangladesh, with wheat a prominent dry-season crop grown with irrigation (Bangladesh Bureau of Statistics; BBS, 2008). Rice is threatened by floods during the pre-monsoon (aus) and monsoon (aman) seasons and by heat waves and water scarcity during the dry monsoon (boro) season.
Boro is currently the most productive season, followed by aman, with aus considerably lower due mostly to smaller planted area (BBS, 2008). Historical cereal production has been increasing for decades, rising from about 10 million metric tons (MT) in the early 1970s to almost 30 MT in 2001 (USDA, 2008). Annual variations and long-term trends in agricultural production come from many factors, including climate events (particularly floods), resource limitations, sociopolitical events, and the implementation of modern agricultural practices, so isolating the sensitivity of historical agricultural production to climate factors is challenging.

\section{Biophysical approach and model framework}

\subsection{Models and methods}

Biophysical process models in this study occupy a range of scales, with crop models focusing on representative farms throughout Bangladesh, river floods simulated over the entire GBM Basins, and coastal inundation determined along the Bangladesh coastline. Differences in the computational resources available for each model limited the ability to set up identical ensembles of climate drivers for each set of model simulations. However, the full range of crop model experiments provided a framework for integrating the highest possible number of river flood and sea level rise simulations and their impact on agricultural lands. This modeling framework was described in Yu et al. (2010), and is therefore only summarized below and in the Supplementary Online Material Appendices.

Fig. 2 describes temperature and precipitation characteristics of the climate scenarios examined in this study, along with baseline observations. Climate scenarios are generated according to local historic conditions and simulated climate changes from global
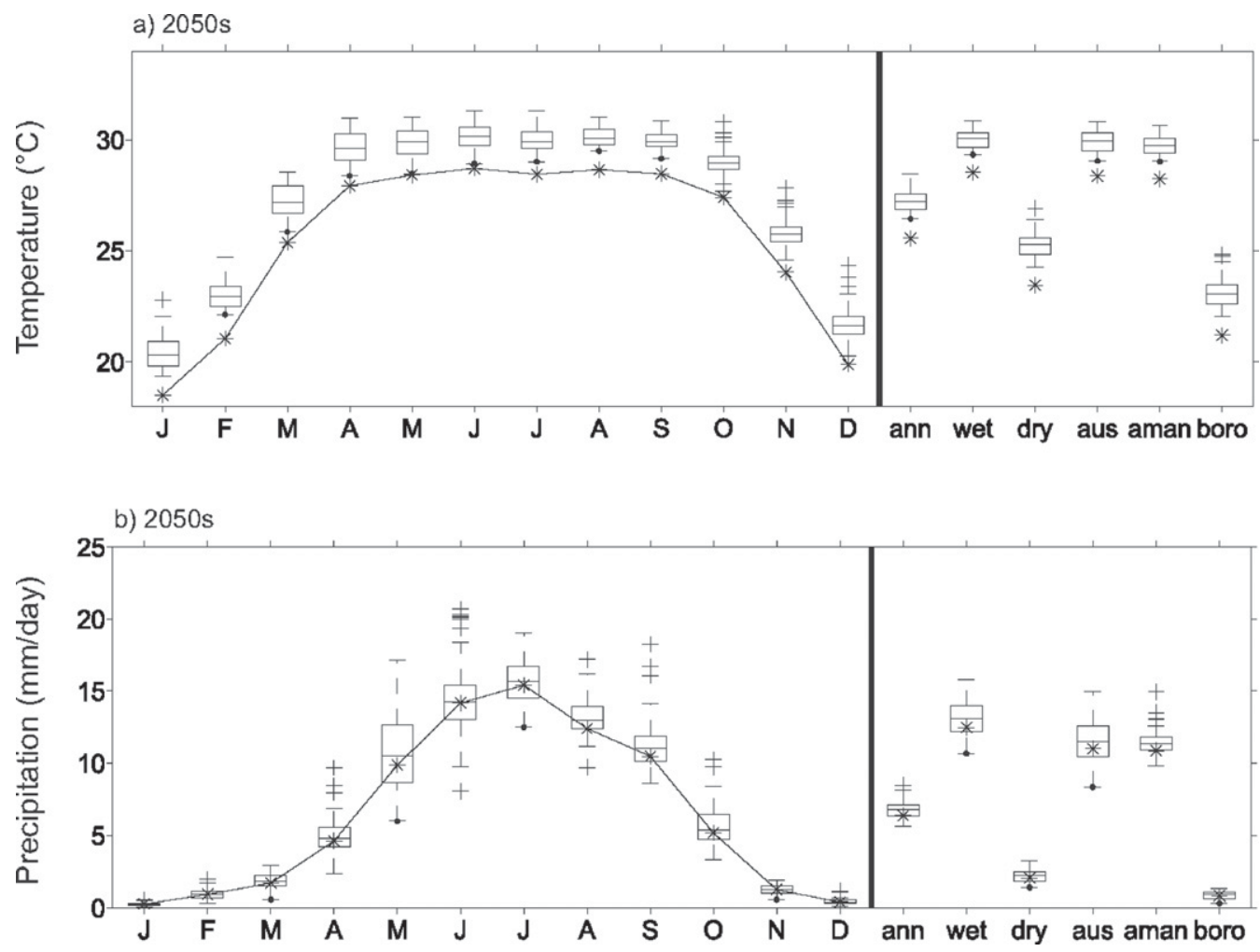

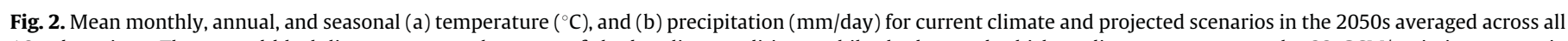
16 sub-regions. The starred black line represents the mean of the baseline conditions, while the box and whiskers diagrams represent the $32 \mathrm{GCM} / \mathrm{emissions}$ scenario combinations for each 30-year period. Note: 'wet' season = May-September; 'dry' = October-April; 'aus' = April-July; 'aman' = July-October; 'boro' = December-March (this is also the wheat season). 
climate model (GCM) output contributed to the World Climate Research Programme's (WCRP's) Coupled Model Intercomparison Project phase 3 (CMIP3) multi-model dataset (Meehl et al., 2007) at the Program for Climate Model Diagnosis and Intercomparison (PCMDI; http://www-pcmdi.llnl.gov). These climate simulations were analyzed by the studies reviewed in the Intergovernmental Panel on Climate Change (IPCC) Fourth Assessment Report (AR4). Climate change scenarios are generated by comparing a given GCM's 2040-2069 period (referred to as the "2050s") with control simulations of that GCM over a 1970-1999 baseline, and then imposing these changes on historical observations (daily rainfall and maximum and minimum temperatures from BMD observations; solar radiation data and short gaps were filled using the Weatherman Utility; Hoogenboom et al., 2003). This delta method (described more completely in Wilby et al., 2004, and Yu et al., 2010) offsets many of the common GCM biases but assumes no change in highfrequency variability or the frequency of rain events. Both a relatively high (A2) and low (B1) future emissions pathway were analyzed and compared to the baseline period, with crop models utilizing representative $\mathrm{CO}_{2}$ concentrations of $556 \mathrm{ppm}, 498 \mathrm{ppm}$, and $345 \mathrm{ppm}$, respectively, set according to projected or observed concentrations in the central year of 30-year the period being studied (SRES, 2000). Following Yu et al. (2010), an ensemble of climate scenarios were created for each sub-region from 16 GCMs and 2 emissions scenarios, capturing a consistent temperature rise and wide uncertainty among projected precipitation changes.

The MIKE BASIN hydrologic model was employed over the entire GBM Basins that drain through Bangladesh to simulate river floods for each baseline and future year. Flood protection infrastructure in Bangladesh was also taken into account by a Bangladeshi flood model (Nishat and Rahman, 2009; Hopson and Webster, 2009). Coastal inundation in the 2050s was simulated by the UK Department for Environment, Food, and Rural Affairs in collaboration with IWM and CEGIS (DEFRA, 2007) using the MIKE21 Two-Dimensional Estuary Model and mean sea levels of $27 \mathrm{~cm}(\sim \mathrm{A} 2)$ and $8 \mathrm{~cm}(\sim \mathrm{B} 1)$ above baseline. More details about the flood models are provided in Appendix II of the Supplementary Online Material.

Process-based crop model simulations were run with the Crop Environment REsource Synthesis (CERES) rice and wheat models from the Decision Support System for Agrotechnology Transfer (DSSAT v4.5.0.030; Hoogenboom et al., 2003; Jones et al., 2003). CERES models require detailed soil profiles, farm-level management practices, genetic coefficients describing the cultivar, and daily meteorological conditions (rainfall, solar radiation, and maximum and minimum temperature). CERES models have been applied extensively in Bangladesh, although less frequently for climate change applications (e.g., Karim et al., 1996; Karim et al., 1994, 1998; Hussain, 2006; Basak et al., 2009). These models include the beneficial effects of enhanced carbon dioxide concentrations on plant growth and are sensitive to the phenological stage of plant development when particular stresses occur, but the exact relationships remain uncertain. For this study the CERES model was calibrated for Bangladeshi sub-regions using soil and cultivar information provided by S.G. Hussain (2008), additional soil profiles drawn from Brammer (1996), and farmlevel management according to practices recommended by the Bangladesh Rice Research Institute (BRRI, 2007).

Crop model simulations for this study utilize modern cultivars and relatively high fertilizer application rates and assume pest-, salinity-, and disease-free conditions. This management configuration follows the recommendations of the Bangladesh Rice Research Institute (BRRI, 2007; presented in Appendix I in the Supplementary Online Material), but is a more intensive management than is typical for many farms in the region. Mahmood et al. (2003) noted the large gap between actual and potential yields in Bangladesh, with actual yield averages approximately $1 / 6$ th of the potential yields produced under unstressed, high-input conditions protected from floods. Projections of future yields provide an indication of the magnitude and direction of climate impacts which will occur on top of the anticipated reduction in this yield gap through economic development.

\section{Definition of sub-regions}

Model and observational data for this project's impacts assessments employ different spatial scales and coverage densities. To overcome the resulting challenge in consistently integrating simulations of different climate impact factors, a common spatial scale was created using available data and resources that groups similar farming areas into 16 sub-regions that cover all of Bangladesh. These sub-regions form the common spatial scale on which climate change factors are compared. Sub-regions were defined according to climatology, agricultural use, terrain, and political boundaries, making them very similar to agro-ecological zones with the added consideration of introducing political boundaries to facilitate clear communication and appropriate jurisdiction over adaptation strategies put into action. These subregions are similar to those developed by Mahmood et al. (2004), but were chosen so as to insure that each had an observation station of the Bangladesh Meteorological Department (BMD) with observations ideally going back to 1970 . The number of sub-regions was limited to be consistent with simulation resources. Fig. 1 shows the 16 sub-regions as defined by the Center for Environment and

Table 1

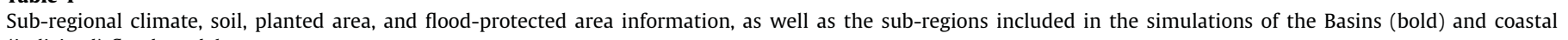
(italicized) flood models.

\begin{tabular}{|c|c|c|c|c|c|c|c|}
\hline Sub-region & BMD climate station & Soil profile location & Aus area (ha) & Aman area (ha) & Boro area (ha) & Wheat area (ha) & Flood-protected area (\%) \\
\hline 1 & Dinajpur & Dinajpur & 65401 & 613853 & 543438 & 174969 & 45 \\
\hline 2 & Rangpur & Rangpur & 42491 & 815334 & 976956 & 149176 & 48 \\
\hline 3 & Ishwardi & Jessore & 21165 & 116985 & 86369 & 53228 & 76 \\
\hline 4 & Tangail & Karatia & 46826 & 239834 & 261113 & 48131 & 15 \\
\hline 5 & Dhaka & Ghatail & 13458 & 51661 & 32107 & 8225 & 9 \\
\hline 6 & Mymensingh & Phulpur & 100018 & 610184 & 561919 & 39339 & 17 \\
\hline 7 & Sylhet & Biani Bazar & 124288 & 350173 & 589900 & 10034 & 27 \\
\hline 8 & Srimangal & Srimangal & 24304 & 64558 & 19294 & 541 & 22 \\
\hline 9 & Comilla & Shalpur & 129498 & 330897 & 426250 & 33260 & 45 \\
\hline 10 & Chittagong & Chittagong & 38209 & 23194 & 74850 & 39 & 31 \\
\hline 11 & Rangamati & Srimangal & 30320 & 14628 & 71881 & 17 & 2 \\
\hline 12 & Maijdee Court & Hatiya & 45945 & 121579 & 26894 & 103 & 58 \\
\hline 13 & Jessore & Jessore & 98834 & 359053 & 333375 & 67317 & 41 \\
\hline 14 & Faridpur & Jessore & 167592 & 351018 & 286413 & 49575 & 38 \\
\hline 15 & Patuakhali & Satkhira & 240201 & 198407 & 162463 & 6399 & 48 \\
\hline 16 & Khulna & Satkhira & 14809 & 215747 & 78225 & 1794 & 35 \\
\hline
\end{tabular}


Table 2

Climate information for each sub-region. The representative BMD station, its code, and annual mean climate statistics during the $1970-1999$ baseline period.

\begin{tabular}{|c|c|c|c|c|c|c|}
\hline Sub-region & BMD station location & BMD station Code & Mean $T_{\max }\left({ }^{\circ} \mathrm{C}\right)$ & Mean $T_{\min }\left({ }^{\circ} \mathrm{C}\right)$ & Mean rainfall (mm) & Mean sunshine $\left(\mathrm{MJ} / \mathrm{m}^{2} /\right.$ day $)$ \\
\hline 1 & Dinajpur & 10120 & 30.1 & 19.7 & 2003 & 16.9 \\
\hline 2 & Rangpur & 10208 & 29.7 & 19.9 & 2239 & 17.2 \\
\hline 3 & Ishwardi & 10910 & 31.0 & 20.3 & 1652 & 17.3 \\
\hline 4 & Tangail & 41909 & 30.3 & 20.8 & 1902 & 16.7 \\
\hline 5 & Dhaka & 11111 & 30.6 & 21.6 & 2148 & 17.6 \\
\hline 6 & Mymensingh & 10609 & 30.0 & 20.5 & 2255 & 16.4 \\
\hline 7 & Sylhet & 10705 & 29.6 & 20.2 & 4150 & 16.7 \\
\hline 8 & Srimangal & 10724 & 30.4 & 19.4 & 2421 & 17.0 \\
\hline 9 & Comilla & 11313 & 30.1 & 20.9 & 2054 & 17.2 \\
\hline 10 & Chittagong & 11921 & 30.2 & 21.6 & 2931 & 18.0 \\
\hline 11 & Rangamati & 12007 & 30.2 & 21.4 & 2532 & 17.0 \\
\hline 12 & Maijdee Court & 11809 & 29.8 & 21.6 & 3103 & 16.9 \\
\hline 13 & Jessore & 11407 & 31.4 & 20.9 & 1600 & 17.2 \\
\hline 14 & Faridpur & 11505 & 30.4 & 21.1 & 1967 & 17.2 \\
\hline 15 & Patuakhali & 12103 & 30.3 & 21.9 & 2704 & 15.6 \\
\hline 16 & Khulna & 11604 & 31.1 & 21.6 & 1812 & 17.4 \\
\hline
\end{tabular}

Geographic Information Services (CEGIS) in conjunction with the rest of the study team.

Agricultural information about each sub-region, including the area growing aus, aman, boro, and wheat, is presented in Table 1. Simulated production in each sub-region is calculated by multiplying the simulated per hectare yield by the agricultural area in each sub-region producing the crop of interest. Agricultural areas were assumed to be constant over the coming century as very little arable land is not currently farmed, and areas are assumed to be evenly distributed across any given sub-region because of the lack of finer-scale information. Mean baseline period climate variables for each sub-region are presented in Table 2.

\section{Climate factors}

\subsection{Direct climate factors}

Direct climate factors are those experienced directly at the farm level from the atmosphere, including changes of temperature, precipitation, $\mathrm{CO}_{2}$ concentrations, and solar radiation that affect crop development.

\subsubsection{Temperature}

Warmer conditions associated with climate change lead to a higher rate of respiration in growing crops, requiring greater amounts of carbon for consumption, speeding up phenological development, and increasing the rate of tissue aging. Temperature changes also affect the timing of seasons, increase potential evapotranspiration, and may push plants closer to damaging thresholds (Solomon et al., 2007; Easterling et al., 2007; Hatfield et al., 2008). The ability of a crop to withstand heat stress depends upon the developmental stage when a heat wave occurs, which is a focus of ongoing research and a sensitivity not completely captured by the CERES models.

To investigate the effects of isolated temperature changes, $\Delta T$ climate scenarios were generated for the CERES crop models to be equal (in radiation, precipitation, and $\mathrm{CO}_{2}$ ) to the 1970-1999 baseline period observations, but with daily maximum and minimum temperatures modified according to mean local monthly changes in each GCM's simulated temperature (i.e., the delta method applied for temperature only; Wilby et al., 2004). For these scenarios the baseline temperature was modified according to the difference between model means for the 2040-2069 period and the means for the 1970-1999 baseline period for each GCM. $\Delta T$ climate scenarios were created for all 16 GCMs for both the A2 and B1 emissions scenarios. At this stage of the analysis, no flood damages were applied.

\subsubsection{Precipitation}

Aus and aman are rainfed crops that periodically experience drought stress (particularly in the northwest). Precipitation changes in future climate simulations vary widely across models and regions, making them among the most uncertain climate change projections. $\Delta P$ climate scenarios isolating the effect of precipitation changes were created for the CERES crop models to be equal (in radiation, minimum temperature, maximum temperature, and $\mathrm{CO}_{2}$ ) to the 1970-1999 baseline period observations, but with daily precipitation totals modified according to mean local monthly percentage changes in each GCM's simulated precipitation (i.e., the delta method for rainfall only; Wilby et al., 2004). These percentage changes are the difference between the GCM's 2040-2069 period values and those for the 1970-1999 baseline period for that GCM. $\Delta P$ climate scenarios were created for all 16 GCMs for both the A2 and B1 emissions scenarios, and no flood damages were applied. Because the boro and wheat cropping areas are assumed to have unlimited irrigation, the impacts of precipitation changes are negligible.

\subsection{3. $\mathrm{CO}_{2}$}

Biophysical crop models, controlled chamber experiments, and Free Air $\mathrm{CO}_{2}$ Enrichment experiments (FACE; Hendry and Kimball, 1994) have demonstrated the relevance of increased $\mathrm{CO}_{2}$ concentrations on agricultural production, but the extent to which largescale field crops will respond to $\mathrm{CO}_{2}$ is the subject of considerable debate (Easterling et al., 2007; Long et al., 2006; Tubiello et al., 2007a, b; Ainsworth et al., 2008; Hatfield et al., 2008; Kimball, 2010; Fleischer et al., 2010) and ongoing research (Boote et al., 2010). $\mathrm{CO}_{2}$ is a primary element of photosynthesis, and plants respond to elevated levels by increasing the rate of primary production. High $\mathrm{CO}_{2}$ concentrations also increase root densities, allow a plant to make more efficient gaseous transfers with its environment, and increase water efficiency (Hatfield et al., 2008). Additional research is needed to determine the agricultural effects of $\mathrm{CO}_{2}$ concentrations for more diverse locations, a wider variety of cultivars, and across fields with a range of nitrogen applications.

To isolate the impact of enhanced $\mathrm{CO}_{2}$ concentrations, $\Delta \mathrm{CO}_{2}$ climate scenarios were generated for the CERES crop models that were identical to the 1970-1999 baseline observations (radiation, minimum temperature, maximum temperature, and precipitation), but where $1985 \mathrm{CO}_{2}$ concentrations (345 ppm; Keeling and Whorf, 2005) were replaced by the center (2055) value of the 2040-2069 period. Because all of the GCMs simulating a given emissions scenario use the same $\mathrm{CO}_{2}$ concentrations, $\Delta \mathrm{CO}_{2}$ climate scenarios were created according to emissions scenario ( $\mathrm{A} 2=556 \mathrm{ppm}$ and $\mathrm{B} 1=498 \mathrm{ppm}$ ) rather than for each GCM. 


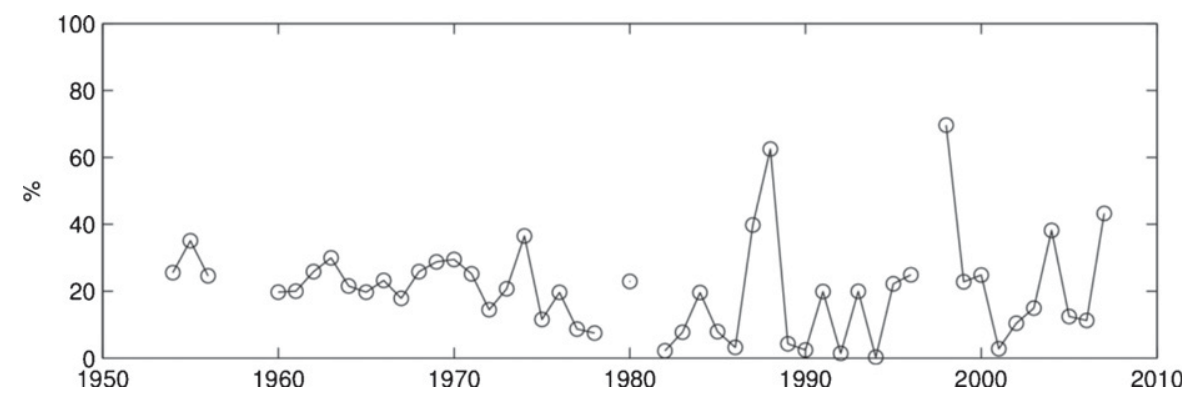

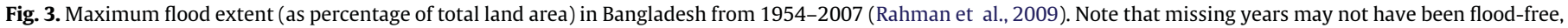
and that Bangladesh's total area is $\sim 144,000 \mathrm{~km}^{2}$.

\subsection{Indirect climate factors}

Crops may also be affected by climate events that originate away from the farm but result in local flooding.

\subsubsection{GBM river floods}

The monsoonal discharge of water from the GBM Basins results in regular seasonal floods affecting Bangladesh with extents varying by year and in response to particular storm events. Inundation of rice crops suffocates gas exchanges necessary for photosynthesis and respiration and can also uproot plants or wash away top soil, reducing overall yields. Fig. 3 shows the areal extent of national floods over recent decades, showing large variations in total extent, and also events that covered nearly $70 \%$ of the total land area (in 1998; Rahman et al., 2009).

Flood damages were calculated using a method adapted from S.G. Hussain, with damages depending on the duration of the flood, the fraction of the plant inundated, and the developmental stage of the crop when the flood strikes (Hussain, 1995; described in Appendix II of the Supplementary Online Material and hereinafter referred to as the Hussain method). Mean plant heights and phenological stages for each calendar day were taken from CERESRice simulations calibrated for the 1970-1999 baseline period under observed meteorological conditions. All land was classified for flood depth, taking areas protected by polders and other flood embankments into account. Simulations were run for the 11 subregions entirely in the GBM Basins (bold names in Table 1) using the MIKE BASIN hydrologic model at the Institute for Water Modeling (Nishat and Rahman, 2009). To isolate the effects of changing GBM river flood extents, $\Delta$ Flood climate scenarios were generated that used baseline values for the direct variables (temperature, precipitation, radiation, and $\mathrm{CO}_{2}$ ), but used modified climate in the GBM Basins for input to the MIKE BASIN hydrologic model. The catchment climates driving river flood simulations were based on 1978-2007, which was the closest 30-year period where GBM conditions were available. These were modified according to each GCM's mean monthly change in simulated temperature and percentage change in simulated precipitation (2040-2069 period in comparison to the 1970-1999 baseline period from that GCM). Differences between the 1970-1999 baseline period used for the crop model scenarios and the 19782007 baseline period used for the river flood models were small in comparison to the differences between 2040-2069 and either of the baseline periods. Due to resource constraints, scenarios from only 5 GCMs (GFDL CM2.1, Delworth et al., 2006; MIROC3.2, medium resolution, Hasumi and Emori, 2004; MPI Echam5, Jungclaus et al., 2006; NCAR CCSM3.0, Collins et al., 2006; and HadCM3, Johns et al., 2006) were developed for the A2, B1, and 20th century (for baseline conditions) scenarios during the monsoon seasons; to our knowledge this is a larger ensemble than has been previously produced for Bangladesh. No sea level rise or direct climate impacts were simulated for crop production at this stage of the analysis. Additional details on the river flood models, the flood damage projections, and the adaptation of the Hussain method for multi-factor model projections are provided in Appendix II of this article's Supplementary Online Material.

\subsubsection{Sea level rise}

Sea levels rise in response to thermal expansion of the oceans, the addition of meltwater from polar caps and alpine glaciers, and local effects including circulation changes and subsidence, erosion, and accretion of land. The resulting net encroachment onto agricultural land is exacerbated by tides and storm surges, which push damaging waves further inland and increase soil salinity. Thus, land areas that were inundated by at least $30 \mathrm{~cm}$ of seawater according to the IWM/CEGIS Bay of Bengal Model (DEFRA, 2007) were assumed not to be available for cereal production. Scenarios were created for the Bay of Bengal model simulations with mean sea level increased to mean 2050 estimates from the IPCC Third Assessment Report (Houghton et al., 2001; McCarthy et al., 2001), and inundation was modeled in 8 coastal sub-regions (italicized names in Table 1). Approximating across coupled GCM projections, DEFRA (2007) created two scenarios for sea level rise above 2000 levels $(A 2=+27 \mathrm{~cm}$; B1 $=+8 \mathrm{~cm})$. Global mean sea level in 2000 was $\sim 3.5 \mathrm{~cm}$ higher than during the 1970-1999 baseline period, so these scenarios slightly underestimate the changes from the baseline period used by the crop model experiments (Church and White, 2006). To isolate the effects of these sea level rises, $\Delta$ SLR scenarios were applied to crop model simulations using the baseline record of direct climate variables (temperature, precipitation, radiation, and $\mathrm{CO}_{2}$ ) without GBM river flooding. Additional details about sea level rise damage calculations are described in Appendix II in the Supplementary Online Material, including a discussion of uncertainty and the likelihood that these projections are optimistic due to an omission of cyclone storm surge (Karim and Mimura, 2008).

\section{Individual climate change factor impacts}

\subsection{Direct climate factor scenarios}

Fig. 4 presents the results of the $\Delta T$ climate scenario experiments, showing reductions in yield from warmer temperatures in all seasons and nearly all sub-regions. The largest declines are projected for the irrigated boro and wheat crops. Wheat experiences the largest median declines from warmer temperatures ( $-12.4 \%$ nationally), with declines of more than $15 \%$ in subregions SR-1 (the largest at $-19 \%$ ), SR-6, SR-11, and SR-15. SR-1 is the most productive sub-region for wheat, while the latter two produce very little wheat at present. Among the ensemble of crop model simulations driven by scenarios from 16 GCMs, median boro production decreases by $12.1 \%$ nationally, with losses of greater than $10 \%$ in 11 sub-regions, including 6 of the top 7 boro-producing sub-regions. Aman is projected to be the crop least affected by 

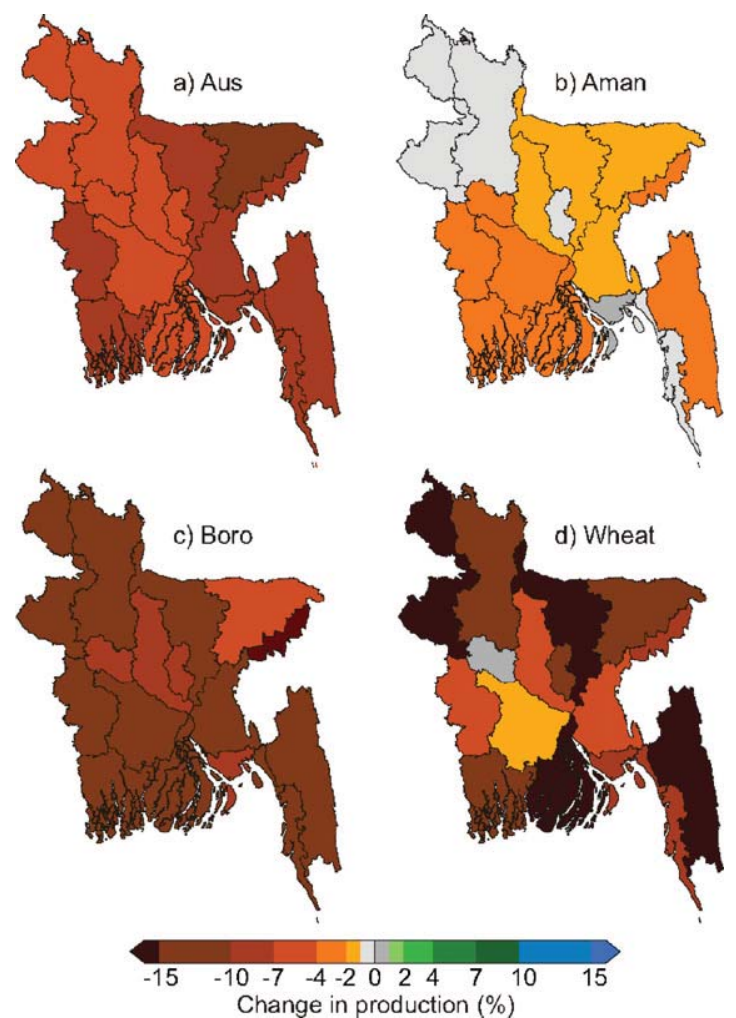

Fig. 4. Median sub-regional production impacts for the $\Delta T$ experiment for (a) aus, (b) aman, (c) boro, and (d) wheat.

temperature (median $-1.5 \%$ national production change), particularly in the highly productive northwest (SR-1, SR-2) where temperatures are slightly cooler than in most of Bangladesh. Median projections show a $-7.3 \%$ median change in national aus production, distributed fairly evenly across nearly all sub-regions, although temperature changes in SR-7 cause more than a $12 \%$ loss in production.

The results of the $\Delta P$ climate scenario experiments for rainfed aus and aman are presented in Fig. 5. Projected rainfall changes reduce median national aus production by $1.4 \%$, with losses in all sub-regions except SR-7 (which shows slight gains of 1.5\%). The largest declines occur in SR-4 (nearly 5\%), although the most productive aus region (SR-15) declines by only $1.2 \%$. Aman simulations were barely sensitive to the projected changes in

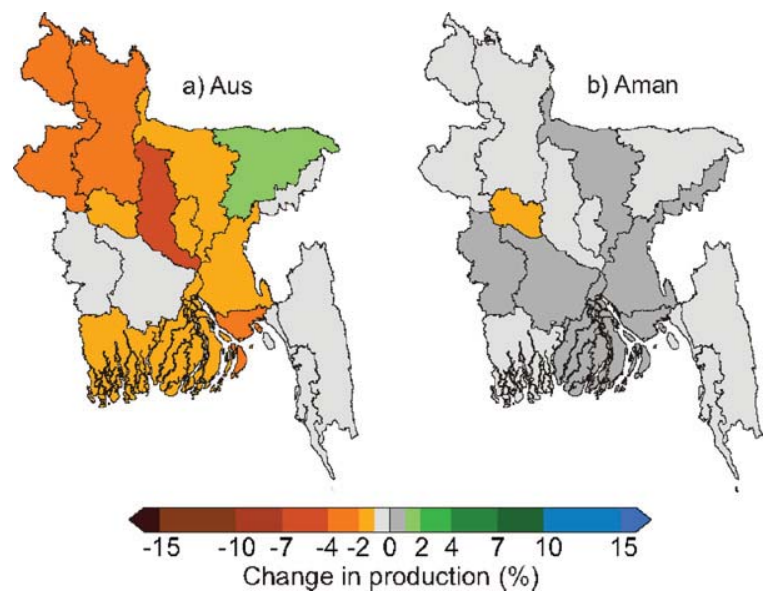

Fig. 5. Median sub-regional production impacts for the $\Delta P$ experiment for (a) aus, (b) aman. Note: irrigated seasons are not shown.
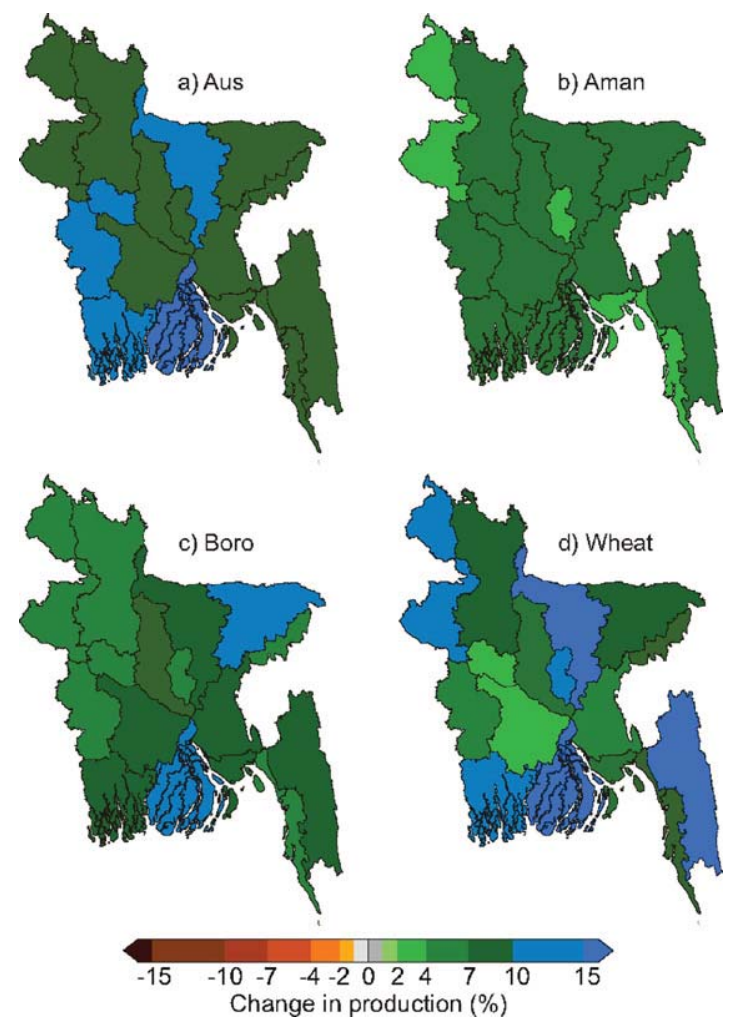

Fig. 6. Median sub-regional production impacts for the $\Delta \mathrm{CO}_{2}$ experiment for (a) aus, (b) aman, (c) boro, and (d) wheat.

rainfall, with only SR-3 and SR-4 near a $1 \%$ median change in production. In general, rainfed aus and aman are not strongly limited by the mean seasonal rainfall, but are likely to be more sensitive to shifts in the variability of damaging dry spells and delayed monsoon onset. These changes, as well as changes in the demand and availability of groundwater (from pumping and natural fluxes) for boro and wheat irrigation, merit further study (e.g., Shahid, 2011; Arnell et al., 2011).

$\Delta \mathrm{CO}_{2}$ scenario results are presented in Fig. 6. As expected, all seasons and sub-regions show gains in production under higher $\mathrm{CO}_{2}$ concentrations with median national production increases of $11.7 \%$ (aus), $4.9 \%$ (aman), $8.3 \%$ (boro), and 10.1\% (wheat). Subregional responses vary, as $\mathrm{CO}_{2}$ concentration changes interact with the soil and weather patterns for sub-regional heterogeneity. Probably reflecting an added benefit from increased water efficiency in plants in higher $\mathrm{CO}_{2}$ concentrations, rainfed aus production gains are the largest among rice seasons. Every subregion sees at least an $8 \%$ increase in aus production; SR-15, which has the largest aus area, leads with more than $15 \%$ gains. In contrast, the wet aman season does not often suffer from water stress and loses more nitrogen to leaching which makes it less able to take full advantage of $\mathrm{CO}_{2}$ enhancement, with gains between $2.5-7 \%$ in all sub-regions. The irrigated boro and wheat seasons have less leaching and show large gains from enhanced $\mathrm{CO}_{2}$, indicating that primary production effects are large. SR-6, SR-15, and SR-16, which were the most sensitive to $\mathrm{CO}_{2}$ concentration changes, had the highest levels of $\mathrm{NH}_{4}$ in their soil profiles, indicating additional nutrient limitations to $\mathrm{CO}_{2}$ effects.

\subsection{Flood hazards}

The effect of mean climate changes on river flood damages are presented in Fig. 7a and b for aus and aman (the dry season crops were assumed to be flood-free). Simulated river flood damages 


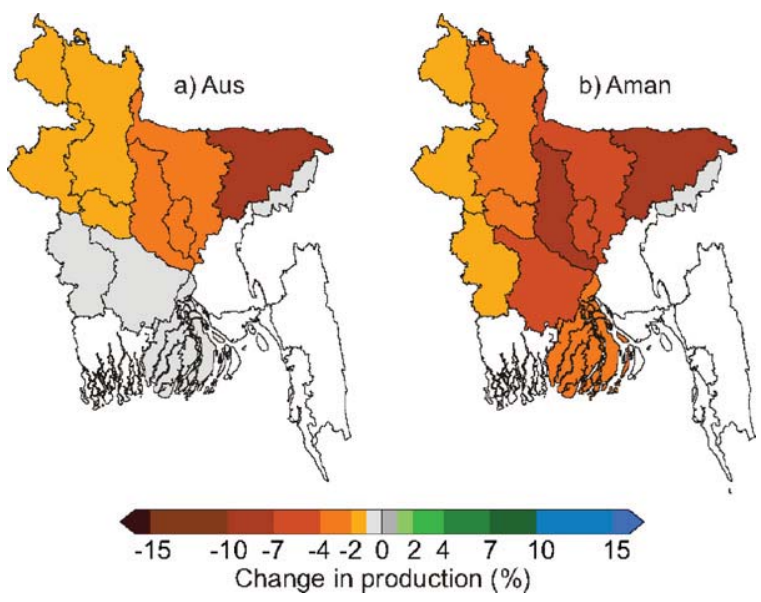

Fig. 7. Median sub-regional production impacts for the $\Delta$ Flood experiment for (a) aus, and (b) aman. Note: Boro and wheat were assumed to be flood-free, and subregions in white were not simulated.

only reduce national aus production by a median of $1.9 \%$, although sub-regions in northern Bangladesh bear the brunt of the early season floods, with the worst damage to the east (Fig. 7a). The highest median increase in flood damages occurs in SR-7 (8.9\% loss in production), where low-lying areas and flash floods are common.

During the later aman season (Fig. 7b), substantial climate change increases in flood damage occur in nearly all sub-regions simulated by the hydrologic model, lowering national production by a median of $3.2 \%$. Increases in damage are generally greater towards the east, with SR-7 (9.2\% loss) and SR-4 (8.2\% loss) showing the largest median damages; however, the eastern hills in SR- 8 are least affected. Although SR- 9 was not simulated by the MIKE BASIN model, its banks of the Meghna are also likely to experience substantial flood damage, similar to the affected subregions that surround it. The mean impact of changing river floods from climate change is much smaller than typical year-to-year flood variations (Fig. 3), but climate change is projected to raise the level of the average flood and make it more likely that extreme events will be damaging. Climate change-induced effects on the frequency and severity of extreme floods merit further study, as more extreme interannual variability would dwarf the river flood impacts of mean climate shifts alone (Mirza, 2002; Yu et al., 2010; Mirza, 2011).

Fig. 8 shows projections of production lost to coastal inundation associated with mean sea level rise (average of A2 and $\mathrm{B} 1$ scenarios). The same percentage of land is lost from the coastal sub-regions in each season, but the dry season crops are disproportionately grown away from the coast, so they are affected less. National losses of 2.3\% (aus), 1.3\% (aman), $0.7 \%$ (boro), and $0.2 \%$ (wheat) are projected when the A2 and B1 scenarios are averaged. Production in SR-16 (-13.3\%) and SR-15 ($8.7 \%$ ) is most affected. As the current world emissions trajectory is higher even than the A2 scenario and sea levels are rising more rapidly than previously thought due to complex ice sheet dynamics (Alley et al., 2005), it is useful to note that the A2 scenario simulations project much higher coastal damages (SR$16=-20 \%$; SR-15 $=-13.1 \% ;$ SR-10 $=-10 \%$ ). Simulations of a $62 \mathrm{~cm}$ rise in mean sea level (estimated for the A2 2080s; DEFRA, 2007) project damages to production because of area loss in excess of $31 \%$ in SR-15 and nearly $40 \%$ in SR-16. With additional vulnerability to severe coastal storms, land subsidence from groundwater extraction and salinity intrusion, these results underscore the long-term threat of sea level rise in Bangladesh (Hassan et al., 2006).
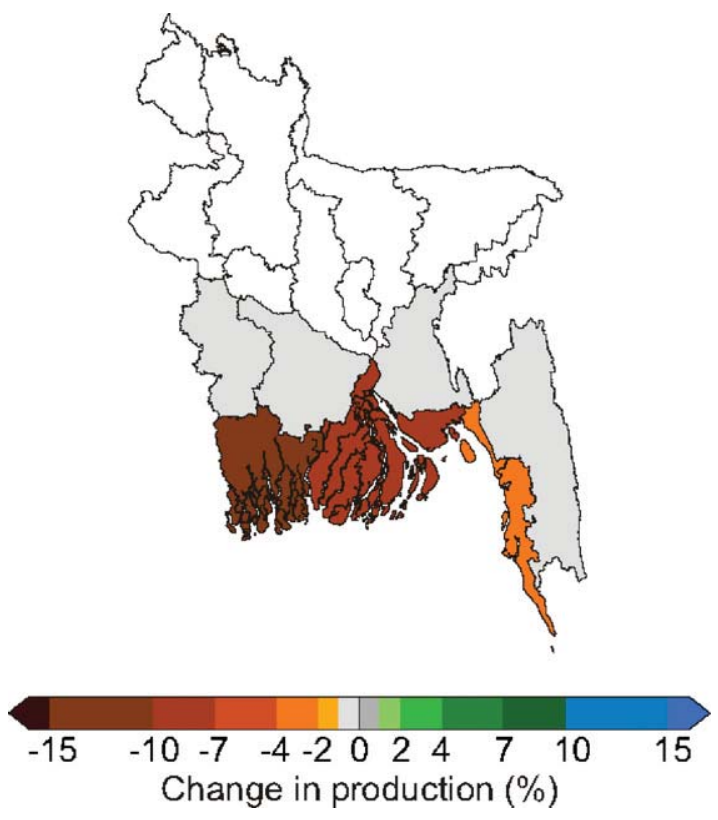

Fig. 8. Mean sub-regional production impacts for the $\Delta$ SLR experiment (average of A2 and B1 scenarios). Note: Sea level rise yield impacts were assumed to affect all seasons equally, and white sub-regions were not simulated.

\section{Integrated sub-regional impacts}

\subsection{Median impacts}

Multi-factor analyses of production changes were conducted for each crop and sub-region, with new scenarios combining changes in the direct climate factors (future temperature, rainfall,

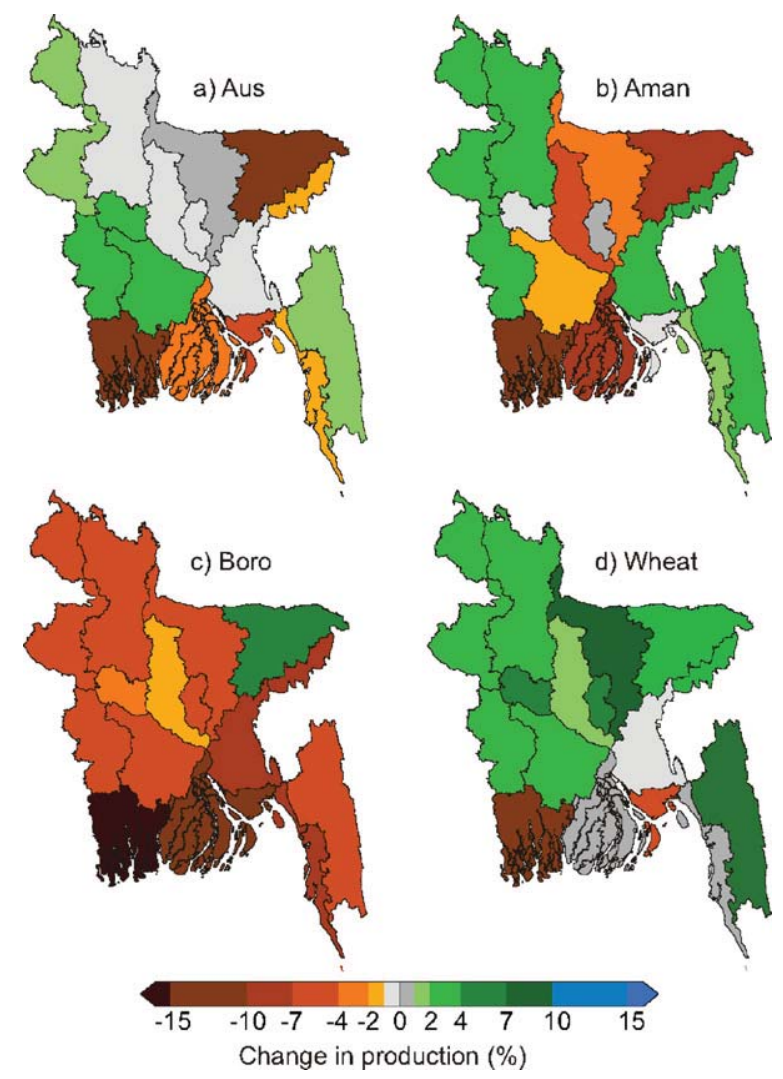

Fig. 9. Median sub-regional production impacts considering all climate factors for (a) aus, (b) aman, (c) boro, and (d) wheat. 
Table 3

Uncertainty analyses for multi-factor production impacts. For each crop and sub-region, the median change across all $32 \mathrm{GCM} / \mathrm{emissions}$ scenario simulations, the absolute difference in the median between the A2 and B1 emissions scenarios ( $\Delta$ SRES), and the average inter-quartile range among GCMs in each emissions scenario ( $\Delta$ GCM) are presented. Shaded boxes indicate that this uncertainty metric makes the sign of the median change difficult to distinguish from zero.

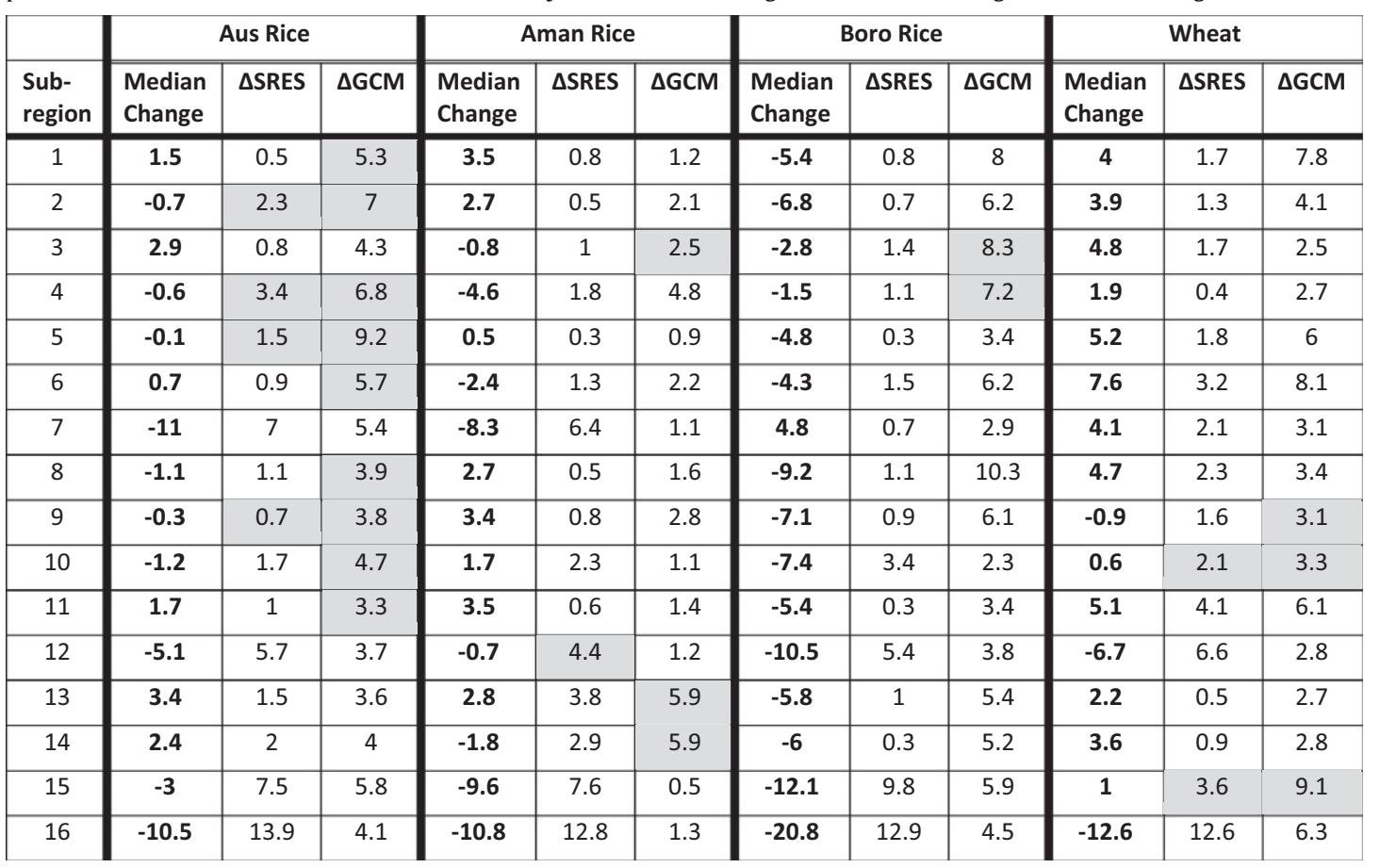

and $\mathrm{CO}_{2}$ concentration changes) with river flood changes and coastal inundation from sea level rise applied as multiplicative factors (Fig. 9 and Table 3 ). As expected, the effects of simultaneous changes in rainfall, temperature, and $\mathrm{CO}_{2}$ concentrations are not the sum or product of each individual factor's effect (Figs. 4-8), as biophysical interactions between direct climate variables are often non-linear. For example, elevated $\mathrm{CO}_{2}$ concentrations can partially mitigate the impact of increased drought, while a combined drought and heat wave can cause more damage than either factor on its own. Sea level rise has a substantial, year-round impact on coastal regions, with damages in SR-16 strongest for each crop. Fig. 8 shows acute sub-regional contrasts that may be overlooked if only the national production is considered.

Aus, in particular, shows a wide contrast between sub-regions with substantial gains (SR-3, SR-13, SR-14) and those with severe losses (SR-7, SR-16; Fig. 9a). The gaining regions are not strongly affected by increases in early-season river floods, and have a favorable balance of potent $\mathrm{CO}_{2}$ enhancement and moderate stresses from increased temperatures. Aus declines in SR-16 are due primarily to sea level rise; SR-7 is projected to suffer from the most severe temperature and flood impacts. The historically most productive aus region (SR-15; Table 1) only experiences a median loss of 3\% due to the strongest $\mathrm{CO}_{2}$ aus enhancement among the sub-regions.

The simulated sub-regional pattern of aman changes reflects the dominance of the indirect climate change factors: river flooding and coastal inundation (Fig. 9b). The effects of the direct climate change factors, on the other hand, are relatively less important and are consistent across all sub-regions. The largest aman damages occur in the coastal region (SR-15, SR-16), followed by often-flooded SR-7 and SR-4 where waters from the Ganges and Brahmaputra meet. Positive changes in SR-9 are probably optimistic because flood damages were not considered there. Aman production increases in the historically most productive sub-region (SR-1), but projections of a gain in SR-2 are somewhat offset by a loss in SR-3 (the next two most productive sub-regions).
Boro simulations show substantial median declines in all subregions except SR-7, which experiences the weakest temperature impact and a strong $\mathrm{CO}_{2}$ enhancement in the part of the country with the most rain and the lowest average maximum temperatures (Fig. 9c). Production losses are the largest on the coast; however, losses are nearly $7 \%$ in SR-2 in the northwest, which is by far the most productive sub-region for boro.

Wheat production is projected to increase in nearly all subregions with substantial historical production (Fig. 9d), although sea level rise affects coastal areas. $\sim 4 \%$ gains are projected for the two most productive wheat sub-regions, SR-1, SR-2 in the northwest; SR-1 experiences strong $\mathrm{CO}_{2}$ and temperature effects while both factors are slightly moderated in SR-2. SR-9 is the only adversely affected sub-region that currently grows large amounts of wheat, owing in part to coastal inundation from sea level rise. Changes in rainfall and river floods have little effect on boro and wheat growth (as they are irrigated in the dry season), but hydrologic effects on groundwater recharge during the monsoon season could have a lasting impact on irrigation water availability that merits further study in a climate change context.

\subsection{Implications of uncertainty}

The integrated multi-factor modeling framework described above enables a detailed examination of climate impacts uncertainty in the impacts assessment process for Bangladesh. It must be emphasized, however, that the uncertainties described reflect the simulation process rather than the true overall predictive uncertainty for Bangladesh, which is also dependent on many factors (known and unknown) not considered in this study.

Table 3 shows two primary sources of framework uncertainty in the combined impacts for each sub-region. The first is related to the differences between societal pathways (via the A2 or B1 emissions scenarios), and the second is related to the differences between the many GCMs simulating future climate. The former depends on policy makers deciding and enforcing international 
emissions targets, while the latter indicates an imperfect model representation that may be improved through continuing GCM development. For each sub-region and crop the following are shown: (1) the median of the 32 futures (16 GCMs $\times 2$ SRES emissions scenarios); (2) $\triangle$ SRES, or the difference between the median of the 16 A2 simulations and the 16 B1 simulations; and (3) $\Delta \mathrm{GCM}$, or the average range of the middle $50 \%$ of the $16 \mathrm{GCM}$ simulations for each emissions scenario. Thus, this table allows projected changes to be put in the context of uncertainty, although the relatively small sample size restricts the application of more robust statistical tests.

In general, uncertainty among GCM projections is larger than that from emissions scenarios, although of course the metrics are different and therefore only broad comparisons may be made. $\triangle$ SRES is largest in coastal regions across all crops, reflecting the importance of societal pathway in the severity of sea level rise damages. Although direct climate factors are not strongly sensitive to emissions scenarios in this time period, the extent of sea level rise depends heavily on changes in the more sensitive Arctic and Antarctic (Shepherd and Wingham, 2007). In SR-7 aus and aman are also highly sensitive to the emissions scenario, which affects the severity of river floods on the Meghna. For all factors (both those with positive and negative production implications), A2 changes are further from zero than the B1 changes due to larger deviations in greenhouse forcing. $\triangle \mathrm{GCM}$ is dependent on the cropping season, with smaller values (on average) for aman, which is more robust to projected changes in direct climate factors, than for other crops.

Many sub-regions' median projected production changes are not statistically separated from zero, as they are closer to zero than half of either $\Delta$ SRES or $\Delta \mathrm{GCM}$. This reflects a substantial number of projected outcomes where the change is of the opposite sign (shaded in Table 3). This is particularly striking for aus, where the strength and timing of pre-monsoon rains and the monsoon onset varies considerably among GCMs, affecting temperatures, rainfall, and flood damages (Bollasina and Nigam, 2009). Aman impacts are quite robust despite relatively small median changes, while boro and wheat changes are mostly large enough to be clearly distinguished from zero. For all sub-regions and crops, Table 3 also demonstrates that the range of simulations includes projections that are considerably more severe than the median change. As the vulnerability of many communities increases non-linearly with the scale of an impact, the full range of projected changes should be examined in designing and prioritizing adaptation strategies.

The individual climate factor impacts in Section 3 may also be used to analyze the sensitivities of combined impacts to errors in each factor. For example, as research continues to reveal the extent to which $\mathrm{CO}_{2}$ is beneficial to tropical rice and wheat production (Hatfield et al., 2008), small changes are likely to have profound implications on these projections as $\mathrm{CO}_{2}$ is the only beneficial factor for most sub-regions and crops. Likewise, insights suggesting increased variability in river floods (e.g. Mirza, 2002), which are not modeled here, could elevate the importance of that climate change factor. Thus, the present work provides a good basis for continuing evaluation of the expected consequences of climate change on agriculture in Bangladesh.

\section{Priority targets for adaptation}

Projections of individual and integrated climate change impact factors reveal the need for adaptation plans on seasonal and subregional (rather than annual and national) levels. These projections aid in assessing the potential benefit of an adaptation strategy, but the costs of implementation and maintenance will also be major considerations (see Yu et al., 2010, for an extensive list of potential adaptation strategies).

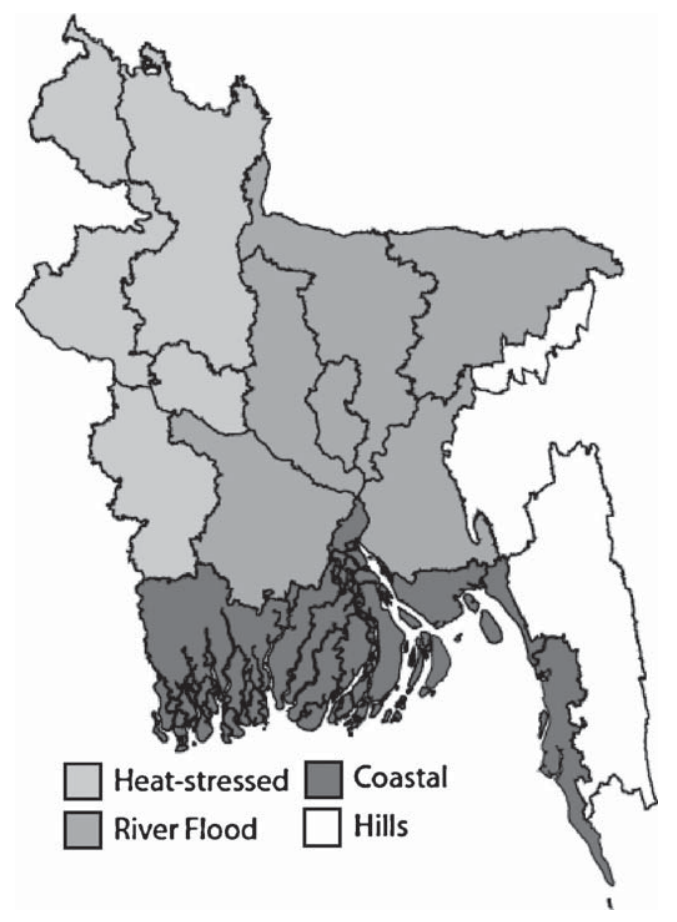

Fig. 10. Regions of Bangladesh with common climate change factors of importance. Farms in these regions face similar challenges from climate change and may be particularly interested in sharing adaptation strategies. Note that the hill tracts subregions (SR-11 and SR-8) do not fit these larger regions.

Adaptations increasing climate resilience in the boro season should target the highest vulnerabilities as stresses from warmer temperatures and limited irrigation are likely to affect this most productive crop across the country. Even accounting for projected negative stresses from climate change impacts, areas introducing irrigation for boro production would increase total production and the ability to offset particularly damaging aman flood losses. Aman appears to be the crop most resilient to direct climate changes, so damages targeting flood protection are projected to be the most beneficial for the aman season. Aus projections are the most uncertain, but the concentration of aus production in SR-15 is a major vulnerability that might suggest some coastal protection. Should irrigation water be available, expanded wheat production is projected to benefit greatly from elevated $\mathrm{CO}_{2}$ concentrations in the first half of this century.

In general, three regions of Bangladesh emerge as having commonalities in the most impactful climate change factors (coastal, river flood, and heat-stressed; Fig. 10). The coastal region is most threatened by sea level rise, and a complex and changing coastline makes permanent protection infeasible. Salinity intrusion and coastal storms add to the mean sea level rise impacts modeled here. The impact of climate change on the river flood region is most dependent on the ways in which monsoon rain and Himalayan snowmelt flow through Bangladesh, with changes in the frequency and intensity of large floods adding to the mean flood changes simulated in this study. Polders and other flood protections could target this vulnerability. In the heat-stressed region, sea level rise and changes in river floods are less impactful, so regional efforts to improve crop resilience to warm temperatures are projected to show the largest local benefit.

\section{Implications and continuing work}

This study has focused on understanding and targeting new vulnerabilities introduced by global climate change in Bangladesh. Benefits may also be realized through adaptations that increase 
resilience to current climate variability, which is likely to obscure the longer-term climate change signal for the next several decades.

By the 2050s, climate change is projected to reduce production in Bangladesh for all three rice seasons, with only wheat $(<5 \%$ of current national cereal production) showing gains. The boro season is expected to be most severely impacted (even when irrigation is unconstrained for existing boro areas). $\mathrm{CO}_{2}$ enhancement, the only climate change factor with positive effects, will likely show diminishing benefits further into the future (Easterling et al., 2007), suggesting that detrimental climate change impacts will accelerate. Year-to-year climate variability, which exists on top of the more gradual changes due to greenhouse gas emissions, will continue to produce variations in agricultural production (for example between normal years and those with heavy floods or strong land-falling cyclones) that are larger than the climate change signal. Only by analyzing a longer period of production (as in the 30-year series examined here) will the climate change signal emerge.

Over the coming decades many other factors will affect Bangladesh's cereal production and obscure a climate signal; including economic development, the expansion of irrigation, wider implementation of modern cultivars, technological improvements, shifting international trade (Schmitz et al., 2012), and the increasing and potentially changing demands of a growing population. Climate change will nevertheless be an additional stress on a country already facing considerable natural and societal challenges to meet the needs of a large and growing population. National production change projections obscure the more acute sub-regional impacts shown in this study that are likely to dominate local production trends unless targeted adaptations are implemented.

Simulations extending out to the 2080s period (conducted as part of Yu et al., 2010) also shed light on the long-term trajectory of climate change impacts in Bangladesh. River floods were not modeled for this period, but temperature, precipitation, and sea level rise continue to have an increasingly negative effect on agriculture while the beneficial effects of $\mathrm{CO}_{2}$ begin to level off. Additionally, the yield response to higher temperatures is not linear; temperatures exceeding critical thresholds during key phenological stages can trigger large production drops or even crop failure. The acceleration in detrimental temperature impacts on wheat is particularly great between the 2050s and 2080s period. Thus, even areas in which climate change is projected to cause increased production in the early $21 \mathrm{st}$ century may face rapidly declining production due to climate factors in later decades if adaptation is not sufficient. Continuing research in agricultural observations, crop model development, and climate model projections will improve our ability to accurately assess these critical processes.

Differences between models and emissions scenarios are substantial, but overall clustering of results suggests that the projections are robust and not strongly prone to divergent sensitivities. Additional uncertainty is introduced through elements that could not be explicitly included in the integrated biophysical factor modeling framework, including:

1. the effects of data-filling processes for climate scenarios;

2. the assumption of stationarity in the statistics of extreme climate events;

3. the use of generalized, high input agricultural management characteristics across Bangladesh;

4. the sensitivity of production to $\mathrm{CO}_{2}$ fertilization, high temperature thresholds, and limited irrigation in the CERES crop models; and

5. the neglected salinity effects and limitations in the simulated coastal domain.
The results of this study therefore should be interpreted through the relative signs and magnitudes of changes for different crops, time periods, and climate scenarios. The spread between GCM-based climate scenarios and emissions scenarios has also been shown to inform the relative uncertainty of impacts when conducting risk assessments.

Time, resources, and data availability limited the full implementation of other considerations that would dramatically improve the quality of this (or future) multi-factor climate change impacts assessment. These include updated sea level rise scenarios including one with more rapid ice melt (e.g., Horton et al., 2011), more realistic irrigation constrained by groundwater availability (Shahid, 2011), routines for salinity damage from irrigation and saltwater intrusion, the use of a weather generator to synthetically increase iterations and better capture extreme events, and climate change interactions with day-to-day and interannual climate variability. Continuing biophysical model development and data collection in Bangladesh will improve future analyses.

The modeling framework used in this work allows for testing interactive adaptations, helping to quantify the "benefit" in costbenefit prioritization. For example, the effects of virtual crops with alternative genetic attributes increasing climate resilience, the construction of additional polders, and coastal levies may all be simulated in this biophysical framework to gauge the impact on national production.

The impact of climate change on the agricultural sector of Bangladesh is also highly dependent on climate impacts on food production in surrounding countries and the major agricultural areas that determine commodity prices. For example, projected impacts in this study have a different implication for Bangladesh if a large portion of other rice-producing countries experience production increases from regional climate changes, and likewise Bangladesh's market share could increase if other rice-producing regions are severely impacted. Understanding such effects is one of the objectives of the Agricultural Model Intercomparison and Improvement Project (AgMIP; Rosenzweig et al., in press), which is now underway and includes a focus on South Asia.

\section{Acknowledgements}

The views expressed herein are those of the authors and do not necessarily reflect the views of their institutions or funders. The authors would like to thank the editors and three anonymous reviewers for their helpful comments and suggestions. This research was supported in part by an appointment to the NASA Postdoctoral Program at the Goddard Institute for Space Studies, administered by Oak Ridge Associated Universities through a contract with NASA, and is a continuation of work initiated by the World Bank. The authors would like to thank Md. Shohel Pervez for his assistance in translating BRRI management guidance, reviewers of the initial World Bank project report that became Yu et al. (2010), World Bank staff in Dhaka, Laura Paulson for map creation, and Gerrit Hoogenboom for his assistance with DSSAT. We acknowledge the modeling groups, the Program for Climate Model Diagnosis and Intercomparison (PCMDI) and the WCRP's Working Group on Coupled Modelling (WGCM) for their roles in making available the WCRP CMIP3 multi-model dataset. Support of this dataset is provided by the Office of Science, U.S. Department of Energy.

\section{Appendix A. Supplementary data}

Supplementary data associated with this article can be found, in the online version, at doi:10.1016/j.gloenvcha.2012.09.001. 


\section{References}

Adger, W.N., Agrawala, S., Mirza, M.M.Q., Conde, C., O’Brien, K., Pulhin, J., Pulwarty, R., Smit, B., Takahashi, K., 2007. Assessment of adaptation practices, options, constraints and capacity. In: Parry, M.L., Canziani, O.F., Palutikof, J.P., van der Linden, P.J., Hanson, C.E. (Eds.), Climate Change 2007: Impacts, Adaptation and Vulnerability. Contribution of Working Group II to the Fourth Assessment Report of the Intergovernmental Panel on Climate Change. Cambridge University Press, Cambridge, UK, pp. 717-743.

Agrawala, S., T. Ota, A.U. Ahmed, J. Smith, and M. van Aalst, 2003: Development and Climate Change in Bangladesh: Focus on Coastal Flooding and the Sundarbans. Environment Directorate and Developmental Co-operation Directorate, Organization for Economic Co-operation and Development, Paris

Ahmed, A.U., 2006. Bangladesh: Climate Change Impacts and Vulnerability. Climate Change Cell, Bangladesh, $42 \mathrm{pp}$.

Ainsworth, et al., 2008. FACE-ing the facts: Inconsistencies and interdependence among field, chamber and modeling studies of elevated $\left[\mathrm{CO}_{2}\right]$ impacts on crop yield and food supply. New Phytologist 5.

Ali, A., 1999. Climate change impacts and adaptation assessment in Bangladesh, Climate Reserach 12, 109-116.

Alley, R.B., Clark, P.U., Huybrechts, P., Joughin, I., 2005. Ice-sheet and sea level changes. Science 310, 456-460.

Arnell, N.W., van Vuuren, D.P., Isaac, M., 2011. The implications of climate policy for the impacts of climate change on global water resources. Global Environmental Change 21 (2011), 592-603, http://dx.doi.org/10.1016/j.gloenvcha.2011.01.015

Asada, H., Matsumoto, J., 2009. Rainfall variation and rice production in India/ Bangladesh. Climate Research 38, 249-260, http://dx.doi.org/10.3354/cr00785.

Ayers, J., Forsyth, T., 2009. Community-based adaptation to climate change: Strengthening resilience through development. Environment Magazine 51 (4), 22-31.

BBS (Bangladesh Bureau of Statistics), 2005. Yearbook of Agricultural Statistics of Bangladesh 2005. In: Chowdhury, J.A. (Eds.), Dhaka, Bangladesh, 344 pp.

BBS, 2008. Handbook of Agricultural Statistics 2007. Dhaka, Bangladesh, available at www.bbs.gov.bd.

Basak, J.K., Ali, M.A., Islam, M.N., Alam, M.J.B., 2009. Assessment of the effect of climate change on boro rice production in Bangladesh using CERES-Rice model. In: Proceedings of the International conference on Climate Change Impacts and Adaptation Strategies for Bangladesh, 18-20 February. pp. 103113.

Bollasina, M., Nigam, S., 2009. Indian Ocean SST, evaporation, and precipitation during the South Asian summer monsoon in IPCC-AR4 coupled simulations. Climat Dynamics 33, 1017-1032, http://dx.doi.org/10.1007/s00382-008- 0477-4.

Boote, K.J., Allen Jr., L.H., Prasad, P.V.V., Jones, J.W., 2010. Testing effects of climate change in crop models. In: Hillel, D., Rosenzweig, C. (Eds.), From the Handbook of Climate Change and Agroecosystems. Imperial College Press, Singapore, pp. 109-129.

BRRI, 2007. Modern Rice Cultivation. Bangladesh Rice Research Institute, Joydebpur, Bangladesh, 66 pp. (available in Bangla).

Brammer, H., 1996. The Geography of the Soils of Bangladesh. University Press, Dhaka, Bangladesh, 287 pp.

Church, J.A., White, N.J., 2006. A 20th century acceleration in global sea-level rise Geophysical Research Letters 33, L01602, http://dx.doi.org/10.1029/ 2005 GL024826.

Collins, W.D., et al., 2006. The Community Climate System Model CCSM3. Journal of Climate 19, 2122-2143.

Delworth, T.L., et al., 2006. GFDL's CM2 global coupled climate models - Part1: Formulation and simulation characteristics. Journal of Climate 19, 643-674.

Department of Environment Food and Rural Affairs (DEFRA), 2007. Investigating the Impact of Relative Sea-Level Rise on Coastal Communities and their Livelihoods in Bangladesh. Report prepared for the UK Department of Environment Food and Rural Affairs by IWM and CEGIS. 137 pp.

Easterling, W., et al., 2007: Food, fibre and forest products. Climate Change 2007. Impacts, Adaptation and Vulnerability. Contribution of Working Group II to the Fourth Assessment Report of the Intergovernmental Panel on Climate Change.In: Parry, M.L., co-editors (Eds.). Cambridge University Press, Cambridge, UK pp. 273-313.

FAOSTAT, 2009. 2009 estimates from the UN Food and Agriculture Organization, from http://faostat.fao.org; accessed April 2012.

Fleischer, D., Timlin, D., Reddy, K.R., Reddy, V.R., Yang, Y., Kim, S.-H., 2010. Effects of $\mathrm{CO}_{2}$ and temperature on crops: Lessons from SPAR growth chambers. In: Hillel, D., Rosenzweig, C. (Eds.), From the Handbook of Climate Change and Agroecosystems. Imperial College Press, Singapore, pp. 55-86.

Hassan, A., et al., 2006. Impact of Sea Level Rise on Landuse Suitability and Adaptation Options. Center for Environment and Geographic Information Services, Dhaka, Bangladesh, p. 153.

Hassan, A., Chowdhury, J.U., Haque, A., 2008. Impact of climate change on riverine flooding in Bangladesh. Presented at the Final CLASIC Project Workshop, June 8th, 2008, BUET, Dhaka, Bangladesh, 16 pp.

Hasumi, H., Emori, S. (Eds.), 2004. K-1 Coupled Model (MIROC) Description, K-1 Technical Report, vol. 1. Center for Climate System Research, University of Tokyo, p. 34.

Hatfield, J., Boote, K., Fay, P., Hahn, L., Izaurralde, C., Kimball, B.A., Mader, T. Morgan, J., Ort, D., Polley, W., Thomson, A., Wolfe, D., 2008. Agriculture. From The effects of climate change on agriculture, land resources, water resources, and biodiversity. A Report by the U.S. Climate Change Science
Program and the Subcommittee on Global Change Research. Washington, DC, USA, $362 \mathrm{pp}$.

Hendry, G.R., Kimball, B.A., 1994. The FACE Programme. Agriculture and Forest Meteorology 70, 3-14

Hoogenboom, G., Jones, J.W., Porter, C.H., Wilkens, P.W., Boote, K.J., Batchelor, W.D. Hunt, L.A., Tsuji, G.Y., 2003. DSSAT v4, vol. 1. University of Hawaii, Honolulu, HI.

Hopson, T., Webster, P., 2009. A 1-10 day ensemble forecasting scheme for the major river basins of Bangladesh: forecasting severe floods of 2003-2007' Journal of Hydrometeorology, http://dx.doi.org/10.1175/2009JHM1006.1.

Horton, R.M., Gornitz, V., Bader, D.A., Ruane, A.C., Goldberg, R., Rosenzweig, C., 2011. Climate hazard assessment for stakeholder adaptation planning in New York City. Journal of Applied Meteorology and Climatology 50 , http://dx.doi.org/ 10.1175/2011JAMC2521.1.

Houghton, J.T., et al., 2001. Climate Change 2001. The Scientific Basis. Contribution of Working Group I to the Third Assessment Report of the Intergovernmenta Panel on Climate Change. In: Houghton, J.T., et al. (Eds.). Cambridge University Press, Cambridge, U.K.

Huq, S., 2001. Climate change and Bangladesh. Science 294, 1617.

Huq, S., Karim, Z., Asaduzzaman, M., Mahtab, F. (Eds.), 1999. Vulnerability and Adaptation to Climate Change in Bangladesh. Kluwer Academic Publishers, Dordrecht, The Netherlands.

Huq, S., Rahman, A., Konate, M., Sokona, Y., Reid, H., 2003. Mainstreaming Adaptation to Climate Change in Least Developed Countries (LDCs). Intenational Institute for Development, London, UK, $40 \mathrm{pp}$.

Hussain, S.G., 1995. Decision support system for assessing rice yield losses from annual flooding in Bangladesh, dissertation submitted to the Graduate Division of the University of Hawaii, p. 137

Hussain, S.G., 2006. Agriculture Water Demand and Drought Modeling. In: Proceedings of Workshop on Climate Change Impact Modeling, Climate Change Cell, Department of Environment, Government of the People's Republic of Bangladesh, Dhaka.

Hussain, 2008. personal communication (November, 2008).

Johns, T.C., et al., 2006. The new Hadley Centre climate model HadGEM1: evaluation of coupled simulations. Journal of Climate 19, 1327-1353.

Jones, J., Hoogenboom, G., Porter, C.H., Boote, K.J., Batchelor, W.D., Hunt, L.A., Wilkens, P.W., Singh, U., Gijsman, A.J., Ritchie, J.T., 2003. The DSSAT cropping system model. European Journal of Agronomy 18 (3-4), 235-265.

Jungclaus, J.H., et al., 2006. Ocean circulation and tropical variability in the AOGCM ECHAM5/MPI-OM. Journal of Climate 19, 3952-3972.

Karim, F.M., Mimura, N., 2008. Impacts of climate change and sea-level rise on cyclonic storm surge floods in Bangladesh. Global Environmental Change 18 490-500.

Karim, Z., Ahmed, M., Hussain, S.G., Rashid, K.B., 1994. Impact of climate change on the production of modern rice in Bangladesh. Implications of Climate Change for International Agriculture: Crop Modeling Study. US Environmental Protection Agency, Washington D.C.

Karim, Z., Hussain, S.G., Ahmed, M., 1996. Assessing impacts of climate variation on foodgrain production in Bangladesh. Journal of Water, Air and Soil Pollution 92, 53-62.

Karim, Z., Hussain, S.G., Ahmed, A.U., 1998. Climate change vulnerability of crop agriculture. Vulnerability and Adaptation to Climate Change for Bangladesh. In: Huq, S., Karim, Z., Asaduzaman, M., Mahtab, F. (Eds.), Kluwer Academic Publishers, Dordrecht, Netherlands, pp. 39-54.

Keeling, C.D., Whorf, T.P., 2005. Atmospheric CO2 records from sites in the SIO air sampling network. Trends: A Compendium of Data on Global Change. Carbon Dioxide Information Analysis Center, Oak Ridge National Laboratory, U.S Department of Energy, Oak Ridge, TN, http://cdiac.esd.ornl.gov/trends/co2/ sio-keel-flask/sio-keel-flask.html.

Kimball, B.A., 2010. Lessons from FACE: $\mathrm{CO}_{2}$ Effects and Interactions with Water, Nitrogen, and Temperature. From the Handbook of Climate Change and Agroecosystems. In: Hillel, D., Rosenzweig, C. (Eds.), Imperial College Press, Singapore pp. 87-107

Long, S.P., Ainsworth, E.A., Leakey, A.D.B., Nösberger, J., Ort, D.R., 2006. Food for thought: lower-than-expected crop yield stimulation with rising $\mathrm{CO} 2$ concentrations. Science 312, 1918-1921.

Mahmood, R., 1997. Impacts of air temperature variations on the boro rice phenology in Bangladesh: implications for irrigation requirements. Agricultural and Forest Meteorology 84, 233-247.

Mahmood, R., 1998. Thermal climate variations and potential modification of the cropping pattern in Bangladesh. Theoretical and Applied Climatology 61, 231-243.

Mahmood, R., Meo, M., Legates, D.R., Morrissey, M.L., 2003. The CERES-Rice modelbased estimates of potential monsoon season rainfed rice productivity in Bangladesh. Professional Geographer 55 (2), 269-273.

Mahmood, R., Legates, D.R., Meo, M., 2004. The role of soil water availability in potential rainfed rice productivity in Bangladesh: applications of the CERESRice model. Applied Geography 24, 139-159.

Master Plan Organization, 1986. National Water Plan. Ministry of Irrigation and Water Development, Dhaka.

McCarthy, J.J., et al., 2001. Climate Change 2001: Impacts, Adaptation, and Vulnerability. Contribution of Working Group II to the Third Assessment Report of the Intergovernmental Panel on Climate Change. In: McCarthy, J.J., et al. (Eds.) Cambridge University Press, Cambridge, U.K.

Meehl, G.A., Covey, C., Delworth, T., Latif, M., McAvaney, B., Mitchell, J.F.B., Stouffer R.J., Taylor, K.E., 2007. The WCRP CMIP3 multi-model dataset: A new era in climate change research. Bulletin of the American Meteorological Society 88, 1383-1394. 
Mirza, M.M.Q., 2002. Global warming and changes in the probability of occurrence of floods in Bangladesh and implications. Global Environmental Change 12,127-138.

Mirza, M.M.Q., 2011. Climate change, flooding in South Asia and implications. Regional Environmental Change 11 (Suppl. 1), S95-S97, http://dx.doi.org/ 10.1007/s10113-010-0184-7.

Ministry of Environment and Forests, 2009. Bangladesh Climate Change Strategy and Action Plan 2009. Dhaka, Bangladesh, 98 pp.

Ministry of Environment and Forests, 2005. National Adaptation Programme of Action. Dhaka, Bangladesh, 46 pp.

Nishat, B., Rahman, S.M.M., 2009. Water resources modeling of the Ganges-Brahmaputra-Meghna River Basins using satellite remote sensing data. Journal of the American Water Resources Association 45 (6), 1313-1327, http:// dx.doi.org/10.1111/j.1752-1688.2009.00374.x.

Parry, M.L., Rosenzweig, C., Iglesias, A., Livermore, M., Fischer, G., 2004. Effects of climate change on global food production under SRES emissions and socioeconomic scenarios. Global Environmental Change 14,53-67, http://dx.doi.org/ 10.1016/j.gloenvcha.2011.01.015

Rahman, A., et al., 2009. Policy Study on the Probable Impacts of Climate Change on Poverty and Economic Growth and the Options of Coping with Adverse Effect of Climate Change in Bangladesh. General Economics Division, Planning Commission, Government of the People's Republic of Bangladesh \& UNDP Bangladesh. Dhaka, Bangladesh, 117 pp.

Rosenzweig, C., Jones, J.W., Hatfield, J.L., Ruane, A.C., Boote, K.J., Thorburn, P., Antle, J.M., Nelson, G.C., Porter, C., Janssen, S., Asseng, S., Basso, B., Ewert, F., Wallach, D., Baigorria, G., Winter, J.M., in press. The Agricultural Model Intercomparison and Improvement Project (AgMIP): Protocols and pilot studies. Agricultural and Forest Meteorology, http://dx.doi.org/10.1016/j.agrformet.2012.09.011.

Sarwar, M.G.M., 2005: Impacts of Sea Level Rise on the Coastal Zone of Bangladesh. Masters Thesis. Lund University, Sweden, $45 \mathrm{pp}$.

Schmitz, C., Biewald, A., Lotze-Campen, H., Popp, A., Dietrich, J.P., Bodirsky, B., Krause, M., Weindl, I., 2012. Trading more food: Implications for land use, greenhouse gas emissions, and the food system. Global Environmental Change 22, 189-209, http://dx.doi.org/10.1016/j.gloenvcha.2011.09.013.

Shahid, S., 2011. Impact of climate change on irrigation water demand of dry season Boro rice in northwest Bangladesh. Climatic Change 105, 433-453, http:// dx.doi.org/10.1007/s10584-010-9895-5.

Shepherd, A., Wingham, D., 2007. Recent sea-level contributions of the Antarctic and Greenland ice sheets. Science 315, 1529-1532.
Solomon, S., et al., 2007. Climate Change 2007: The Scientific Basis. Contribution of Working Group I to the Fourth Assessment Report of the Intergovernmental Panel on Climate Change. In: Solomon, S., et al. (Eds.). Cambridge University Press, Cambridge, U.K.

SRES, 2000. Special Report on Emissions Scenarios, A Special Report of Working Group III of the Intergovernmental Panel on Climate Change, Nakicenovic, N. and co-authors, Cambridge University Press, Cambridge, UK, 599 pp.

Tanner, T.M., Hassan, A., Islam, K.M.N., Conway, D., Mechler, R., Ahmed, A.U., Alam, M., 2007. ORCHID: Piloting Climate Risk Screening in Bangladesh Detailed Research Report. Institute of Developmental Studies, University of Sussex, Brighton, UK.

Thomalla, F., Cannon, T., Huq, S., Klein, R.J.T., Schaerer, C., 2005. Mainstreaming Adaptation to Climate Change in Coastal Bangladesh by building Civil Society Alliances. Proceedings of the Solutions to Coastal Disasters Conference 2005 , American Society of Civil Engineers (ASCE), Charleston, South Carolina, USA, 811 May, pp. 668-684.

Timsina, J., Humphreys, E., 2006. Applications of CERES-Rice and CERES-Wheat in research policy and climate change studies in asia: a review. International Journal of Agricultural Research 1 (3), 202-225.

Timsina, J., Adhikari, B., Ganesh, K.C., 1997. Modelling and simulation of rice, wheat, and maize crops for selected sites and the potential effects of climate change on their productivity in Nepal. Consultancy Report submitted to Ministry of Agriculture, Harihar Bhawan, Kathmandu, Nepal. 55 pp.

Tubiello, F.N., et al., 2007a. Crop response to elevated CO2 and world food supply; A comment on "Food for Thought.." by Long et al., Science 312:1918-1921, 2006. European Journal of Agronomy 26, 215-223.

Tubiello, F.N., Soussana, J.-F., Howden, S.M., 2007b. Crop and pasture response to climate change. PNAS 104 (50), 19686-19690, http://dx.doi.org/10.1073/ pnas.0701728104.

United States Department of Agriculture, 2008. Foreign Agriculutral Statistics (USDA FAS), available at http://www.fas.usda.gov/psdonline. Accessed April 4th, 2008.

Wilby, R.L., Charles, S., Zorita, E., Timbal, B., Whetton, P. and Mearns, L., 2004. Guidelines for use of climate scenarios developed from statistical downscaling methods. IPCC Supporting Material, available from the DDC of IPPC TGCIA.

Yu, W.H., Alam, M., Hassan, A., Khan, A.S., Ruane, A.C., Rosenzweig, C., Major, D.C., Thurlow, J., 2010. Climate Change Risks and Food Security in Bangladesh. Earthscan, Washington, DC 